\title{
THE EFFECT OF WEBSITE QUALITY FEATURES AND COGNITIVE ABSORPTION ON SOCIAL NETWORK SITE USAGE: A CROSS-NATIONAL STUDY
}

\author{
Ya-Hui Hsu \\ Ming Chuan University \\ No. 250, Zhong Shan N. Rd., Sec. 5, Taipei City 111, Taiwan \\ yahui_hsu@msn.com \\ Chien-Kuo Li \\ Shin Chien University \\ No. 70, Dazhi St., Taipei City 104, Taiwan \\ ckli@mail.usc.edu.tw \\ Chien-Ming Li \\ Ming Chuan University \\ No. 250, Zhong Shan N. Rd., Sec. 5, Taipei City 111, Taiwan \\ hotjack0615@hotmail.com \\ Na-Ting Liu \\ Ming Chuan University \\ No. 250, Zhong Shan N. Rd., Sec. 5, Taipei City 111, Taiwan \\ nating@ms55.hinet.net
}

\begin{abstract}
Social network sites (SNSs) have become an essential interpersonal communication tool, and the number of global SNSs users is increasing at an astonishing rate. To fill the research gap on SNSs, this study examined the rarely discussed influence of website quality features and cognitive absorption on SNS acceptance. This cross-sectional study focused on comparing 250 users from Taiwan and 200 users from Indonesia to contribute to the growing field of information system (IS) and information technology (IT) literature on SNSs. Structural equation modeling (SEM) and multi-group analysis were used to analyze the data. The results indicated similarities and differences between the two countries, confirming that the effect of country moderates the SNS usage. This study demonstrated that website quality features attract users based on the perceived ease of use and perceived
\end{abstract}


usefulness. Feelings of temporal dissociation, heightened enjoyment, and curiosity also arouse users' intentions to use SNSs.

Keywords: Social network site, Technology Acceptance Model, Website Quality Features, Cognitive Absorption, Cross-National Research

\section{INTRODUCTION}

Social network sites (SNSs), such as MySpace, Twitter, and Facebook, have attracted millions of users since their introduction. Boyd and Ellison ${ }^{1,2}$ defined SNSs as web-based services that allow people to (1) construct a public or semi-public profile within a bounded system, (2) generate a list of other users with whom they share a connection, and (3) view and navigate their list of connections and connections made by others within the system. SNSs are structured primarily by personal or egocentric networks rather than by interests in early public online communities ${ }^{3}$. These social networks are driven mostly by pre-existing groups of friends. People join the sites with their friends to share cultural artifacts and ideas and communicate with each other ${ }^{4}$. SNSs also allow users to comment on their friends' profiles. Profiles, friend lists, and public comments are three key features of $\mathrm{SNSs}^{2,5}$.

Undeniably, SNSs popularity has grown. SNSs offer the means to make either business (e.g., LinkedIn) or social connections (e.g., MySpace, Orkut, and Facebook). SNSs provide distinguishing features to cater to diverse users by incorporating new information technology (IT) communication tools, such as mobile, blogging, and photo or video-sharing services ${ }^{6}$. In addition to these new technologies, users are also informed about what their friends are doing and thinking, easily replying to their opinions and advice, controlling what others can see and know about them, and tailoring the platform with extensions and applications. Users can change their preferences if an SNS does not meet their requirements ${ }^{1}$. Therefore, it is essential to examine customer perceptions of SNSs and understand the antecedents of SNSs usage ${ }^{7}$. These perceptions may be used to effectively manage $\mathrm{SNSs}^{8}$.

Sledgianowski and Kulviwat ${ }^{9}$ used the Social Network Site Adoption model to predict SNS usage and behavioral intention (BI) through examining users' perceptions of playfulness, critical mass, normative pressure, trust, usefulness, and ease of use. They also suggested that the factors that contribute to increasing web performance, such as content, customization, and security, should be explored and confirmed in the future. DeLone and McLean ${ }^{10}$ developed the updated DeLone and McLean (D\&M) 
model, which proposes that system quality, information quality, and service quality (referred to as website quality features in this study) affect both information system (IS) user satisfaction and BI. Lin ${ }^{11}$ and $\operatorname{Lin}^{12}$ stated that three online quality factors (information quality, system quality, and service quality) are critical determinants of perceived usefulness (PU) and two online quality factors (system quality and service quality) have a strong effect on the perceived ease of use (PEOU) of the virtual community. Furthermore, Petter, DeLone, and McLean ${ }^{13}$ suggested that website quality features may be relevant or should be measured differently if they are applied to social networking or other types of IS that are used for enjoyment. Based on these references, this study considered website quality features to increase our understanding of SNSs.

Although users search websites for specific information, they also want to surf them for entertainment purposes and even to socialize ${ }^{14}$. Flow is a subjective human and computer-mediated interaction experience, representing a user's perception of his or her interaction with a site either as playful and exploratory ${ }^{15}, 16$. This study adopted Agarwal and Karahanna ${ }^{17}$ concept of cognitive absorption (CA) to represent flow experience and serve as an important antecedent of two essential beliefs, PU and PEOU, which are relevant to technology use and SNSs to discover specific determinants of CA that are essential to user perceptions. Huang ${ }^{18}$ felt that the web attributes of a website, such as complexity, novelty, and interactivity, could be used to enhance online enjoyment. However, few studies have applied the comprehensive view to explain the relationship between website characteristics and flow experience ${ }^{14,19}$. Therefore, this study further aimed to clarify the relationship between website quality features and CA.

The purpose of this study was to test the applicability of the technology acceptance model (TAM) for predicting SNS adoption and usage in Taiwan and Indonesia. First, we used Taiwan and Indonesia as survey subjects because they exhibit different internet penetration environments in terms of their telecommunication infrastructure and internet usage behavior. Taiwan has one of the most advanced telecommunications networks in Asia with a high national internet penetration rate of $79.18 \%$ and a household internet penetration rate of $84.81 \%{ }^{20}$. In addition, Facebook Inc.'s penetration rate in Taiwan (65\%) is higher compared to the penetration rate of any other market in the world ${ }^{21}$. By contrast, Indonesia, ranking fourth in the Internet penetration rate in Asia, is the third largest country in Asia, but its broadband market is still developing ${ }^{22}$. Nevertheless, Indonesia has more Facebook users compared to the United Kingdom, and it is the second largest Facebook market, with 35.2 million users, just behind the United States $^{23}$. 
Second, although TAM has been widely applied and tested by several previous empirical studies conducted in North America, Straub et al. ${ }^{24}$ suggested that this work should be applied to other regions of the world. Durvasula et al. ${ }^{25}$ expressed "a need for testing models cross-nationally because all too often, researchers have assumed that US-based concepts and models are relevant to other countries without actual validation of model constructs or linkages. This assumption can lead to invalid cross-national inferences." Therefore, although we compared only two countries in this study, the study tests the research framework with Taiwanese and Indonesian SNS users.

Finally, website users from different countries prefer different website characteristics that meet their distinct navigation, security, customer service, and other feature requirements ${ }^{26}$. To distinguish the differences between the two countries, we integrated website quality features and CA constructs into the TAM to further understand SNSs.

\section{LITERATURE REVIEW}

\subsection{TAM}

The TAM is among the most powerful and widely applied theories for predicting and explaining user behavior during IS implementation ${ }^{27}$. It suggests that the PU and PEOU of IT are the major determinants of IS usage $^{28}$. PU is defined as "the degree to which a person believes that using a particular system would enhance his or her job performance ${ }^{28,}$ PU is a measure of someone's subjective assessment of the utility offered by the new IT in a specific task-related context. PEOU is described as "the degree to which a person believes that using a particular system would be free of effort $^{28,}$ PEOU is an indicator of the cognitive effort required to learn and use new IT. In addition, the original TAM included the constructs of attitudes toward use, BI to use, and actual use.

Moon and $\mathrm{Kim}^{29}$ extended the TAM to World-Wide-Web (WWW) usage and used three dimensions of perceived playfulness (concentration, curiosity, and enjoyment) to measure a user's intrinsic acceptance of WWW. They found that playfulness may be a critical aspect of interface design and that PEOU exerts a more significant effect on individual attitudes compared to PU. Lin and $\mathrm{Lu}^{8}$ applied IS quality (information quality, response time, and system quality) to understand user perceptions of websites. Koufaris ${ }^{30}$ and $\mathrm{Hsu}$ and $\mathrm{Lu}^{31}$ used flow theory integrated with the TAM to understand online behavior. $\operatorname{Lin}^{11}$ also successfully applied the TAM in a virtual community by using online features (information quality, system quality, 
and service quality). Mulero ${ }^{32}$ used TAM to investigate the effect of social networks marketing (SNM) system of small and medium-scale enterprises (SMEs) in South Africa. Elkaseh, Wong, and Fung ${ }^{33}$ showed that the use of social networking media played an important role in the adoption of e-learning in Libyan higher education. The PEOU and PU greatly influenced the use of social networking media for e-learning in Libyan higher education. When SNSs are used primarily for hedonic purposes rather than utilitarian purposes, hedonic system developers should use hedonic content, animated images, and aesthetically appealing visual layouts to provide self-fulfilling value and to encourage prolonged use ${ }^{34}$. Extending the TAM, future studies should identify the determinants that affect the success of SNSs ${ }^{9}$.

\subsection{Updated DeLone and McLean Information System Success Model}

DeLone and McLean ${ }^{10}$ IS success model has been modified to evaluate the success of specific applications in many areas, such as knowledge management ${ }^{35}$, ecommerce ${ }^{36,37}$, and virtual communities ${ }^{12}$. However, the D\&M model has not been used to investigate gaming, social networking, and other types of IS that are used for enjoyment ${ }^{10}$. Sledgianowski and Kulviwat $^{9}$ wanted future research to identify more factors, such as SNS content, customization, and security, because these significant predictors may be useful for SNS design, and they may help improve website usability.

\subsection{Cognitive Absorption}

A website provides information, offers services, and enriches people's experience. Maximizing engaging experiences in the online environment is the central concern of SNS providers ${ }^{19}$. As the content and format of websites evolve, a website becomes an environment that provides different activities. Activities, such as entertainment, exploration, communication, knowledge, and learning may provide website users with interactivity and involvement, allowing them to experience flow ${ }^{38}$. The flow experience is easily recognizable to avid rock climbers, composers, and even web surfers $^{39}$. Hoffman and Novak ${ }^{15}$ argued that flow is a central construct in the hypermedia environment and that the benefits of flow online include exploratory and positive behaviors and positive subjective experiences. Flow can affect outcomes, such as navigation behavior and repeat visits to commercial websites.

CA is a conceptual construct of an intrinsic motivation-related variable described by Agarwal and Karahanna ${ }^{17}$. Studies have examined the relationship between CA and a dimension called absorption ${ }^{40}$, the state of 
flow $^{41}$, and the notion of cognitive engagement ${ }^{42}$. Csikszentmihalyi and LeFevre ${ }^{41}$ characterized flow as a state of optimal experience that can occur in the pursuit of physical activities and in interactions with symbolic systems, such as mathematics and computer languages. Agarwal and Karahanna ${ }^{17}$ believed that CA is an essential antecedent to salient beliefs regarding IT in the study of technology use behavior. Agarwal and Karahanna ${ }^{17}$ described five dimensions of CA used to study IT use behavior: (1) temporal dissociation, or the inability to register the passage of time while engaged in interaction; (2) focused immersion, or the experience of total engagement where other attentional demands are ignored; (3) heightened enjoyment, which captures the pleasurable aspects of an interaction; (4) control, which represents the user's perception of being in charge of an interaction; and (5) curiosity, or the extent to which an experience arouses a person's sensory and cognitive curiosity.

\section{RESEARCH MODEL AND HYPOTHESES}

The model in this study was based on the original TAM (cf. Davis ${ }^{28}$ ), updated IS Success Model (cf. DeLone \& McLean ${ }^{10}$ ), and CA concept (cf. Agarwal \& Karahanna $^{17}$ ). The extensions of the TAM included website quality features and CA as antecedents of user beliefs. This study also proposed that website quality features affect CA.

\subsection{Technology Acceptance Model}

The main purpose of the original TAM was to explain and predict user acceptance of an IS by using the data that are quantitatively measured after a brief period of interaction with the system. In the original TAM, PU was considered a significant factor that predicted BI, and PU was greatly influenced by $\mathrm{PEOU}^{28,43,44}$. Until now, the TAM has been repeatedly evaluated and modified for various IS applications ${ }^{43,45,46}$. In a TAM study, Davis et al. $^{43}$ found that PU predicted BI, whereas PEOU exerted a secondary effect and acted through PU. Igbaria et al. ${ }^{47}$ also determined that PEOU was a dominant factor in explaining PU and system use.

When computer users want to use new technology, the TAM is able to reasonably depict user intentions to use technology ${ }^{48}$. Users are more inclined to fully examine and use SNS features and functions if they find an IS useful ${ }^{49}$. SNSs support a wide range of interests and practices with various technological developments ${ }^{3}$. The more users perceive SNSs as useful and easy to use, the more they intend to use SNSs and the more they actually use the sites. Based on this statement, we proposed four hypotheses:

H1: PEOU positively influences the PU of an SNS. 
H2: PEOU positively influences the intention to use an SNS.

H3: PU positively influences the intention to use an SNS.

H4: The intention to use an SNS positively influences actual SNS usage.

\subsection{Website Quality Features and the Technology Acceptance Model}

Researchers have proposed a number of models to explain what makes ISs successful. DeLone and McLean ${ }^{10}$ used three dimensions (information quality, system quality, and service quality) to predict IS success. IS researchers have been widely using D\&M model to understand IS usage behavior, as they have found that the model offers a useful framework for organizing measurements of IS success. Web practitioners are also concerned with the web quality features of SNSs, which appear to affect user acceptance because SNS companies control web quality features to influence user beliefs and $\mathrm{BI}^{50}$.

SNSs provide a mechanism for informing users of what their friends are doing and thinking, and they grant users easy access to the opinions and advice of their friends. Sharing videos, blogging, and instant messaging also allow users to network effortlessly with their friends. Without the cues provided by face-to-face contact, information sharing and exchange through SNSs require accurate, complete, and current information ${ }^{12}$. Lin and $\mathrm{Lu}^{8}$ suggested that websites that provide higher quality information improve the PU of users. Lederer et al. ${ }^{51}$ also found that information quality and PU share a significant relationship. Nelson et al. ${ }^{52}$ concluded that information quality, such as completeness, currency, and relevance, facilitate the completion of a task. An IS that provides unfavorable data can adversely influence a user's task performance and alter users' perceptions of IS usefulness $^{49}$. In other words, users classify the information provided by a website as useful if the quality of information on the website is accurate, informative, and current $^{53}$. Furthermore, web technologies provide user-customized or multi-media content, which is interactive and easy to understand. A high level of information quality enables users to make superior decisions ${ }^{54}$. The quality of information on an SNS is a vital determinant of whether users feel that a website is useful and easy to use. Therefore, we hypothesized that information quality exerts a positive effect on the PEOU and PU of an SNS.

H5a. Information quality positively influences the PEOU of an SNS.

H5b. Information quality positively influences the PU of an SNS. 
System quality of a Web-based IS measures the functionality that the website provides ${ }^{11}$. System reliability, convenient access, rapid response time, and system flexibility are examples of the qualities that users value ${ }^{10}$. Nelson et al. ${ }^{52}$ emphasized that reliability is the most influential determinant of system quality. Ahn et al. ${ }^{50}$ also argued that a website is designed within an IS and that system quality is an essential measure of a website. Lin $^{12}$ reported that a satisfied virtual community requires a high quality system to allow users to identify social groups easily, navigate using a search engine, and exchange information efficiently. Lederer et al. ${ }^{51}$ and Liao and Cheung ${ }^{55}$ demonstrated that system capabilities that provide users with more convenience, privacy, and faster responses positively affected the PEOU and PU of a website. User perceptions of IS usefulness are strengthened if the IS provides access to multiple services through a single integrated interface ${ }^{49}$. Users are more likely to interact with those SNSs that encourage users to design their own SNS, such as Ning, or to build applications to personalize their platforms, such as Facebook. Users use these SNSs more frequently when system quality conforms to their daily use requirements. Therefore, we expected system quality to positively affect the PEOU and PU of an SNS.

H6a. System quality positively influences the PEOU of an SNS.

H6b. System quality positively influences the PU of an SNS.

DeLone and McLean ${ }^{10}$ argued that service quality is a significant dimension of IS success because customer service is crucial in the ecommerce environment. In addition, service quality is a useful predictor of the PEOU and PU of a website ${ }^{50}$. Lin ${ }^{12}$ suggested that online businesses and communities should provide trust mechanisms and effective customer support. On an SNS, more services, such as a good-designed interface, improve the quality of customer service. Furthermore, users consider whether their needs will be met before using an SNS because they do not want to have unpleasant experiences. Service quality helps system providers assess the relative importance of users' overall quality perceptions ${ }^{56}$. Therefore, we hypothesized that better service quality positively affects the PEOU and PU of an SNS.

H7a. Service quality positively influences the PEOU of an SNS.

H7b. Service quality positively influences the PU of an SNS. 


\subsection{Cognitive Absorption and Technology Acceptance Model}

Flow constructs have been proposed as essential for understanding the nature of user online experiences when the Web is a part of people's daily lives $^{57}$. CA has been applied to online shopping, mobile device usage ${ }^{58,59}$, and IS implementation ${ }^{60}$. Venkatesh ${ }^{61}$ conceptualized intrinsic enjoyment as $^{6}$ an antecedent of PEOU. Yi and Hwang ${ }^{62}$ proposed intrinsic motives, such as intrinsic enjoyment of PU, in their study. Venkatesh et al. ${ }^{63}$ also confirmed that intrinsic motivation increases the deliberation and thoroughness of cognitive processing, thus leading to enhanced perceptions of extrinsic motivation (i.e., PU).

On a SNS, intrinsically motivating state of CA decreases the perceived cognitive burden associated with a task. Activities associated with flow include researching the Web, reading or replying to news or emails, playing games, and chatting on the Internet ${ }^{38}$. Because people experience pleasure and are willing to expend more effort on a task, a lower cognitive burden amplifies the PEOU ${ }^{17}$. The relationship between CA and PU is derived from self-perception theory ${ }^{64}$, which argues that individuals seek to create additional reasons or justifications to rationalize their actions to reduce cognitive dissonance. When users spend their time interacting with a system and experience gratification, most social environments accept the instrumental outcomes. Moreover, users rationalize their efforts by attributing instrumental value to them to reduce cognitive dissonance. This is achieved by overlooking the hedonistic or pleasurable aspects of an activity. A situation occurs when a user uses SNSs and convinces him or herself that, "I am voluntarily spending a lot of time on this and enjoying it, therefore, it must be useful ${ }^{65}$ ".

When using an SNS for hedonic purposes, users try to find instrumental value in the SNS, which involves, for example, communicating with customers or being informed of urgent projects, to extend the benefits of using the SNS. Similarly, "feeling pleasant and being intrigued by the technology, the person would positively estimate the potential consequences of using the technology toward his/her goals (i.e., PU) ${ }^{9}$. Koufaris ${ }^{30}$ found that enjoyment of flow was positively related to intention to return to a SNS. Van der Heijden ${ }^{34}$ also indicated that perceived enjoyment is a stronger predictor of the intention to use hedonic systems, such as online games or SNSs. Hoffman and Novak ${ }^{15}$ argued that flow could affect outcomes, such as navigation patterns as well as repeated visits to commercial website. The benefits of flow, including increased learning, exploratory behavior, positive subjective experiences, and a perceived sense of control, increase users' 
intentions to use SNSs. Therefore, based on these assumptions, we proposed the following hypotheses:

H8a. CA positively influences the PEOU of an SNS.

H8b. CA positively influences the PU of an SNS.

H8c. CA positively influences the BI of an SNS.

\subsection{Website Quality Features and Cognitive Absorption}

Skadberg and Kimmel $^{19}$ attempted to build a flow model based on a website browsing context. From a design, performance, experience, and content perspective, they argued that attractiveness and speed influence flow experiences, such as time distortion and enjoyment. Skadberg et al. ${ }^{66}$ revealed that flow experience is closely related to users' acceptance of information in learning. The research also found that flow experience was characterized by time distortion, enjoyment, and telepresence while browsing a web site. Huang ${ }^{18}$ also identified significant effects of responsiveness, individualization, navigability, reciprocity, synchronicity, participation, and demonstrability on flow experience (control, attention, curiosity, and interest). In addition, Chung and $\operatorname{Tan}^{14}$ reported that cognitive aspects, website characteristics, and search motivation are the antecedents of perceived playfulness and that they play a dominant role in influencing a user's feeling of playfulness. Koufaris ${ }^{30}$ suggested that using value-added search mechanisms and high quality information (varied, complete, detailed, accurate, timely, relevant, and reliable) could make shopping experiences more fulfilling and enjoyable. SNSs offer various web technologies, including audio-visual support, user-customized or multi-media content, and multiple communication mechanisms for accepting user complaints ${ }^{54}$. These functionalities create optimal SNS experiences because they create feelings of exhilaration when using an SNS-similar to the relationship between website quality features and CA. Therefore, we proposed that:

H9a. When using an SNS, information quality positively influences CA.

H9b. When using an SNS, system quality positively influences CA.

H9c. When using an SNS, service quality positively influences CA.

\subsection{Moderating Effect of Country}

Liao and Cheung ${ }^{55}$ stated that culture plays a significant role in the behavior of internet users. Davis ${ }^{28}$ called for more research using the TAM to understand how cross-cultural differences affect the adoption and use of new technologies. Singh et al. ${ }^{67}$ used Brazilian, German, and Taiwanese 
samples to examine international website usage and found a strong support for the applicability of the TAM. Carli et al. ${ }^{68}$ compared Italian students and American students in the quality of experience based on flow and control and demonstrated that the Italians preferred to experience flow and the Americans preferred to experience both flow and control. Lee et al. ${ }^{69}$ attempted to identify the determinants of customer satisfaction during online shopping and found that American and Korean consumers differed in website functionality and aesthetic qualities requirements. Thus, we expected the results of the proposed model to differ across countries or cultures, where the country variable moderates the strength of the effect. Therefore, we proposed the following hypothesis:

H10. "Country" moderates the relationship in the proposed model; therefore, relationships will vary across countries.

In summary, TAM incorporated website quality features and CA to investigate the determinants of SNS use. The research model is shown in Figure 1.

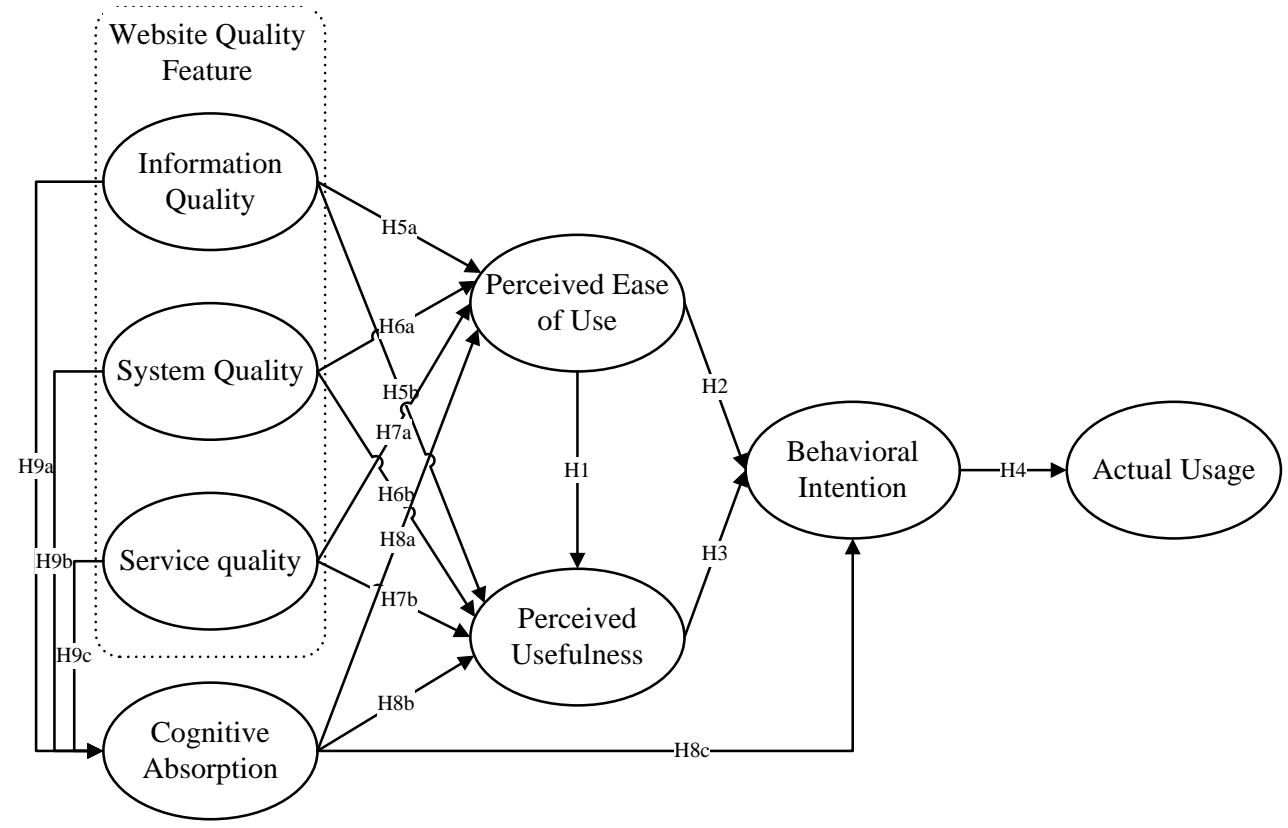

Figure 1. Research framework 


\section{RESEARCH METHODOLOGY}

\subsection{Participants}

In this study, samples from two countries were drawn. First, to target registered SNS users, a Web-based survey was employed. An email message that explained the research objectives and contained the link to the Web-based survey was sent to the members of SNSs. Second, students from several high schools and universities located in Taiwan and Indonesia who were members of SNSs were asked to complete the survey.

Undergraduate students and young adults are an appropriate target group for a survey of SNS usage behavior. Young adults and adolescents are the most active internet users in Taiwan ${ }^{20}$. In Indonesia, youth between 15 and 19 years old have the greatest access to the internet (31.81\%), followed by 20 to 24 years old users $(17.81 \%)^{70}$. This study recruited 280 respondents from Taiwan and 250 respondents from Indonesia. After deleting the missing data, we had 250 and 200 complete and usable questionnaires, representing response rates of $89 \%$ and $80 \%$ from Taiwan and Indonesia, respectively. Table 1 shows the respondents' demographic characteristics, including their gender and age. Table 2 shows a summary of the statistics used to measure whether respondents used SNSs to search for someone with whom they shared a connection, such as a classmate or friend.

The questionnaire was first developed in the English language, and it was later translated into Chinese by a bilingual professor who was a native Chinese speaker. The Chinese questionnaire was then back translated into English to confirm the accuracy of the terminology ${ }^{71}$. A few minor disagreements resulted from the use of certain Chinese terms, and these disagreements were discussed until consensus was reached. The same method was used to translate Indonesian questionnaire to ensure that the measurement instruments reflected the same meanings. Specially, the multi-dimensional constructs of CA were modified from 20 items to 14 items after reliability analysis testing ${ }^{58}$.

Table 1. Profile of respondents

\begin{tabular}{|c|c|c|c|c|c|}
\hline \multicolumn{2}{|c|}{ Demographic characteristics } & \multicolumn{2}{|c|}{ Taiwan } & \multicolumn{2}{|c|}{ Indonesia } \\
\hline Measure & Item & Frequency & Percentas & Frequenc & Percentage \\
\hline \multirow{3}{*}{ Gender } & Male & 110 & 0.44 & 97 & 0.49 \\
\hline & Female & 140 & 0.56 & 103 & 0.51 \\
\hline & $<20$ & 35 & 0.14 & 105 & 0.525 \\
\hline \multirow[t]{2}{*}{ Age } & $21-25$ & 152 & 0.608 & 94 & 0.470 \\
\hline & $>25$ & 63 & 0.252 & 1 & 0.005 \\
\hline
\end{tabular}


Table 2. Summary statistics for SNS for prior contacts and meeting new people

\begin{tabular}{lcccc}
\hline \multirow{2}{*}{ Individual Item and Scale $^{1}$} & \multicolumn{2}{c}{ Taiwan } & \multicolumn{2}{c}{ Indonesia } \\
& Mean & S.D & Mean & S.D \\
\hline $\begin{array}{l}\text { I have used SNS to check out someone I met } \\
\text { Socially. }\end{array}$ & 4.91 & 1.33 & 5.01 & 1.53 \\
$\begin{array}{l}\text { I use SNS to learn more about other people in my } \\
\text { classes/works. }\end{array}$ & 5.24 & 1.22 & 4.93 & 1.45 \\
$\begin{array}{l}\text { I use SNS to learn more about other people living } \\
\text { near me. }\end{array}$ & 4.57 & 1.75 & 4.66 & 1.51 \\
$\begin{array}{l}\text { I use SNS to keep in touch with my old friends. } \\
\text { I use SNS to meet new people }\end{array}$ & 5.38 & 1.20 & 5.59 & 1.39 \\
\hline
\end{tabular}

Note: ${ }^{1}$ Individual items ranged from $1=$ strongly disagree to $7=$ strongly agree, scales constructed by taking mean of items.

\subsection{Measures}

To examine the effect of website quality features and CA on SNSs, structural equation modeling (SEM) was used to identify factors and to measure the influence of website quality features and CA endogenous variables on the PEOU, PU, BI, and actual behavior (AB) endogenous variables. We used SEM to test the proposed model; to provide an assessment of its predictive validity, specifically regarding the direct and indirect relationships among the latent variables; and to quantify the explained and unexplained variance in the model ${ }^{72,73}$. All constructs were assessed using multiple items measured on a 7-point Likert-type scale (ranging from $1=$ strongly disagree to $7=$ strongly agree). The constructs were adapted primarily from previous studies but were modified for an SNS context.

Website Quality Features. Website quality features comprise three types of quality, information quality, system quality, and service quality. Information quality includes six aspects, information accuracy, completeness, currency, format of the information presentation, customization, and relevance ${ }^{52,74}$. Four items comprise system quality, system reliability, convenience of access, response time, and system flexibility ${ }^{10,75}$. Service quality includes five aspects: visual appeal, trustworthiness, responsiveness, and empathy ${ }^{76,77,78}$. This study focused on SNSs by applying research methods used by $\operatorname{Lin}^{75}$ and Lin and Lee ${ }^{77}$ who studied virtual communities, which are similar to online environments, such as SNSs.

$\boldsymbol{C A}$. The CA concept was adapted from the original study by Agarwal and Karahanna ${ }^{17}$ and further modified by Shang et al. ${ }^{58}$. Fourteen items are 
used to measure CA, including temporal dissociation, focus immersion, heightened enjoyment, control, and curiosity dimensions.

TAM. PEOU and PU attributes were measured using modified multiple-item perceptual scales published by Davis ${ }^{28}$, Venkatesh ${ }^{61}$, and Wang et al. ${ }^{79}$. Three BI items from Davis ${ }^{28}$, Venkatesh ${ }^{61}$, and Wang et al. ${ }^{79}$ were measured by asking participants whether they would join an SNS and whether they would use an SNS if they had access to one. Actual usage behavior was measured using two items adopted from Wang et al. ${ }^{79}$ that asked users about the frequency with which they use SNSs.

\subsection{Construct Validity}

As shown in Table 3, confirmatory factor analysis (CFA) was conducted to test the measurement model. All constructs in the two samples comprised identical items. Consistent with the suggestion by Anderson and Gerbing ${ }^{80}$ to purify the measurement model, we eliminated items that loaded on multiple constructs or exhibited low item-to-construct loadings. The loadings of items on their respective factors were highly significant ( $p$ $<.01)$. The composite reliabilities of all constructs exceeded the 0.7 threshold for field research ${ }^{81}$. The average extracted variances approached the recommended 0.5 level $^{81}$, meaning that the hypothesized constructs accounted for most of the variance observed in the items. To maintain CA integrity, the focus immersion item for the average extracted variance of CA was kept at 0.472 . Convergent validity was also assessed using the factor loadings from the CFA (see Table 4). Based on the recommendation by Hair et al. ${ }^{81}$, factor loadings above 0.5 were considered significant. Fornell ${ }^{82}$ proposed a stricter loading criterion that is greater than 0.7. All of the factor loadings in the research model were greater than 0.5 , and most of them were above 0.7. Therefore, all constructs in the model demonstrated adequate reliability and convergent validity.

To examine discriminant validity, we used the procedures suggested by Fornell and Larcker ${ }^{83}$. The results indicated that the average variance extracted by the measure of each factor was larger compared to the squared correlation of each factor's measure with measures of other factors in the model (see Table 4). These values suggest that all factors in the two measurement models display strong discriminant validity. 
Table 3. Factor loadings, composite reliability, and average variance extracted

\begin{tabular}{lcc}
\hline Variables & Taiwan & Indonesia \\
\hline Cognitive Absorption & & \\
While using SNS, I am able to block out most other distraction & 0.53 & 0.54 \\
I have fun interacting with SNS & 0.82 & 0.80 \\
Using SNS provides me with a lot of enjoyment & 0.77 & 0.83 \\
I enjoy using SNS & 0.80 & 0.83 \\
Using SNS excites my curiosity & 0.56 & 0.67 \\
Interacting with SNS makes me curious & 0.58 & 0.66 \\
$\quad$ Composite reliability & 0.83 & 0.87 \\
$\quad$ Average variance extracted (AVE) & 0.47 & 0.53 \\
Information Quality & & \\
The information provided by SNS is accurate & 0.72 & 0.82 \\
SNS provides me with a complete set of information & 0.75 & 0.83 \\
The information from SNS is always up to date & 0.69 & 0.67 \\
The information provided by SNS is well formatted & 0.82 & 0.77 \\
SNS provides me with all the information I need & 0.69 & 0.80 \\
$\quad$ Composite reliability & 0.85 & 0.89 \\
$\quad$ Average variance extracted (AVE) & 0.54 & 0.61 \\
System Quality & & \\
SNS operates reliably & 0.78 & 0.78 \\
SNS allows information to be readily accessible to me & 0.75 & 0.73 \\
$\quad$ Composite reliability & 0.74 & 0.73 \\
$\quad$ Average variance extracted (AVE) & 0.59 & 0.57 \\
Service Quality & & \\
SNS does not show a sincere interest in solving members' problems & 0.80 & 0.73 \\
SNS does not give prompt service & 0.85 & 0.80 \\
$\quad$ Composite reliability & 0.81 & 0.74 \\
Average variance extracted (AVE) & 0.68 & 0.59 \\
Perceived Ease of Use & & \\
My interaction with SNS is clear and understandable & 0.82 & 0.80 \\
Interacting with SNS does not require a lot of mental effort & 0.82 & 0.76 \\
I find SNS easy to use & 0.94 & 0.75 \\
I find it easy to get SNS to do what I want it to do & 0.82 & 0.73 \\
$\quad$ Composite reliability & 0.91 & 0.85 \\
$\quad$ Average variance extracted (AVE) & 0.73 & 0.58 \\
Perceived Usefulness & & \\
using SNS increases my personal productivity & 0.82 & 0.84 \\
Using SNS enhances my personal effectiveness & 0.89 & 0.88 \\
I find my SNS to be useful in my life & 0.78 & 0.76 \\
$\quad$ Composite reliability & 0.87 & 0.87 \\
$\quad$ Average variance extracted (AVE) & 0.69 \\
\hline
\end{tabular}


Table 3. Factor loadings, composite reliability, and average variance extracted (Cont.)

\begin{tabular}{lcc}
\hline Variables & Taiwan & Indonesia \\
\hline Intention to Use & & \\
Assuming I am not registered on SNS, I intent to sign up for SNS & 0.83 & 0.81 \\
Assuming I have access to SNS, I intend to use it & 0.93 & 0.88 \\
Given that I have access to SNS, I predict that I will use it & 0.89 & 0.83 \\
$\quad$ Composite reliability & 0.91 & 0.88 \\
$\quad$ Average variance extracted (AVE) & 0.78 & 0.71 \\
Actual Usage Behavior & & \\
I use SNS frequently. & 0.95 & 0.92 \\
I usually use SNS whenever I use a computer & 0.86 & 0.80 \\
$\quad$ Composite reliability & 0.90 & 0.85 \\
$\quad$ Average variance extracted (AVE) & 0.82 & 0.74 \\
\hline Model fit statistics & Taiwan & Indonesia \\
X2 & 598.419 & 451.029 \\
Degrees of freedom & 296 & 296 \\
P-value & 0.00 & 0.00 \\
Normed Fit Index (NFI) & 0.937 & 0.961 \\
Non-Normed Fit Index (NNFI) & 0.961 & 0.986 \\
Comparative Fit Index (CFI) & 0.967 & 0.988 \\
Incremental Fit Index (IFI) & 0.967 & 0.988 \\
Root Mean Square Error of Approximation (RMSEA) & 0.064 & 0.051 \\
\hline
\end{tabular}

Table 4. Average variance extracted and shared variance estimates

\begin{tabular}{lcccccccc}
\hline Taiwan data & 1 & 2 & 3 & 4 & 5 & 6 & 7 & 8 \\
\hline 1. Cognitive absorption & 0.69 & & & & & & & \\
2. Information quality & 0.49 & 0.74 & & & & & & \\
3. System quality & 0.58 & 0.63 & 0.77 & & & & & \\
4. Service quality & 0.36 & 0.65 & 0.58 & 0.83 & & & & \\
5. Perceived ease of use & 0.40 & 0.36 & 0.38 & 0.35 & 0.85 & & & \\
6. Perceived usefulness & 0.38 & 0.56 & 0.46 & 0.58 & 0.29 & 0.83 & & \\
7. Intention to use & 0.53 & 0.28 & 0.39 & 0.28 & 0.49 & 0.42 & 0.88 & \\
8. Actual usage behavior & 0.41 & 0.18 & 0.16 & 0.12 & 0.35 & 0.20 & 0.46 & 0.91 \\
\hline Indonesia data & 1 & 2 & 3 & 4 & 5 & 6 & 7 & 8 \\
\hline 1. Cognitive absorption & 0.73 & & & & & & & \\
2. Information quality & 0.63 & 0.78 & & & & & & \\
3. System quality & 0.65 & 0.62 & 0.76 & & & & & \\
4. Service quality & 0.35 & 0.50 & 0.31 & 0.77 & & & & \\
5. Perceived ease of use & 0.67 & 0.64 & 0.54 & 0.27 & 0.76 & & & \\
6. Perceived usefulness & 0.64 & 0.62 & 0.55 & 0.47 & 0.62 & 0.83 & & \\
7. Intention to use & 0.69 & 0.47 & 0.52 & 0.21 & 0.65 & 0.64 & 0.84 & \\
8. Actual usage behavior & 0.58 & 0.30 & 0.42 & 0.17 & 0.38 & 0.42 & 0.53 & 0.86 \\
\hline
\end{tabular}

Note: Diagonals represent the square root average variance extracted. Other entries represent the shared variance. 
Finally, we followed the procedure recommended by Bagozzi and $\mathrm{Yi}^{84}$ to evaluate the fit of the measurement model for the two countries. The fit indices of the CFA model, including the Normed Fit Index (NFI), Non-Normed Fit Index (NNFI), Comparative Fit Index (CFI), and Incremental Fit Index (IFI), ranged from 0.93 to 0.10 for Taiwan and Indonesia. Furthermore, the root mean square of error approximation (RMSEA) values were 0.064 for Taiwan and 0.051 for Indonesia. Overall, these fit indices suggest that the CFA model for the two countries adequately fit the data ${ }^{85}$. In summary, the measurement model demonstrated adequate reliability, convergent validity, and discriminant validity.

\subsection{Measurement Invariance}

To determine whether the same models apply to different populations or countries, we tested for measurement invariance across the two countries using the method suggested by Myers et al. ${ }^{86}$. As shown in Table 5, a test of configural variance (Model 1) produced $\chi 2=1260.635$ with 619 degrees of freedom $(d f)$. As shown in Table 6, the CFI was 0.969 and RMSEA was 0.068. These fit indices indicated that the model fit the data well. These findings demonstrated that the two countries exhibit the same simple factor structure and that the same baseline model can be used for each sample population $^{87}$.

The second model (Model 2) examined whether the factor covariances of the two countries are equal. This was accomplished by using the same value for $\Phi$ in the two groups. The results in Table 6 show that the chi-square difference between the simple structure model (Model 1) and the equal variance model (Model 2) was 37.185 with 28 df. This was not significant at $p<.05$, indicating that the factor correlations were invariant across the two countries.

In Model 3, the factor loadings ( $\lambda$ ) for the two countries were equal for all questionnaire items. This produced $\chi^{2}=1334.036$ with $d f=646, \mathrm{CFI}=$ 0.968 and RMSEA $=0.689$. The chi-square values between the constrained model (Model 3) and unconstrained model (Model 1) were significantly different $(\Delta \chi 2=73.401, \Delta d f=27, p<.05)$. Consequently, we tested Model 4 in which both the factor correlations and factor loadings were constrained to be equal. The difference between Model 3 and Model 4 was not significant $(\Delta \chi 2=41.207, \Delta d f=28, p<.05)$. These results indicated that although the factor structure was consistent across the two countries, the latent constructs were composed differently in relation to the measured variables. Hence, measurement models were invariant across the Indonesian and Taiwanese samples. 
Table 5. Data Analysis

\begin{tabular}{|c|c|c|}
\hline Analysis & Model & Purpose \\
\hline Measurement model & $\begin{array}{l}\text { Perform confirmatory factor analysis for } \\
\text { the Indonesia and Taiwan }\end{array}$ & Test construct validity \\
\hline $\begin{array}{l}\text { Measurement } \\
\text { invariance (1) }\end{array}$ & $\begin{array}{c}\text { Perform multi-group CFA (Model 1) for } \\
\text { the Indonesia and Taiwan simultaneously } \\
\text { in which no constraints are imposed } \\
\text { across groups }\end{array}$ & $\begin{array}{l}\text { Test for configural } \\
\text { invariance across } \\
\text { countries }\end{array}$ \\
\hline $\begin{array}{l}\text { Measurement } \\
\text { invariance (2) }\end{array}$ & $\begin{array}{l}\text { Perform multi-group CFA (Model 2) by } \\
\text { constraining the correlations among the } \\
\text { factors in two groups }\end{array}$ & $\begin{array}{l}\text { Test nomological } \\
\text { validity }\end{array}$ \\
\hline $\begin{array}{l}\text { Measurement } \\
\text { invariance (3) }\end{array}$ & $\begin{array}{c}\text { Perform multi-group CFA (Model 3) by } \\
\text { constraining the factor loadings across } \\
\text { two groups }\end{array}$ & $\begin{array}{l}\text { Establish metric } \\
\text { equivalence }\end{array}$ \\
\hline $\begin{array}{l}\text { Measurement } \\
\text { invariance (4) }\end{array}$ & $\begin{array}{l}\text { Perform multi-group CFA (Model 4) by } \\
\text { constraining both the factor correlations } \\
\text { and the factor loadings across two groups }\end{array}$ & $\begin{array}{c}\text { Examine the } \\
\text { composition of } \\
\text { constructs with respect } \\
\text { to variables across } \\
\text { countries }\end{array}$ \\
\hline Hypothesis testing & $\begin{array}{l}\text { Test hypothesized model with individual } \\
\text { country sample and multi-group } \\
\text { structural model for the Indonesia and } \\
\text { Taiwan simultaneously }\end{array}$ & $\begin{array}{l}\text { Examine structural } \\
\text { equivalence across } \\
\text { countries }\end{array}$ \\
\hline
\end{tabular}

Source: Myers, M. B., Calantone, R. J., Page, T. J., \& Taylor, C. R. (2000). An Application of Multiple-Group Causal Models in Assessing Cross-Cultural Measurement Equivalence. Journal of International Marketing, 8(4), 108-121.

Table 6. Measurement equivalence tests through a CFA constrained at several levels

\begin{tabular}{cccccc}
\hline Model & $\chi^{2}$ & df & p-value & CFI & RMSEA \\
\hline Model 1: unconstrained & 1260.635 & 619 & 0.00 & 0.969 & 0.068 \\
Model 2: Фconstrained & 1297.820 & 647 & 0.00 & 0.968 & 0.067 \\
Model 3: $\lambda$ constrained & 1334.036 & 646 & 0.00 & 0.968 & 0.069 \\
Model 4: $\Phi, \lambda$ & 1375.243 & 674 & 0.00 & 0.966 & 0.068 \\
constrained & & & & & \\
\hline
\end{tabular}

\subsection{Structural Equation Modeling Analysis and Hypothesis Testing}

As shown in Table 7, the hypothesized model was estimated individually for each of the two countries. The Taiwan model did not support H1, indicating that PEOU was not positively related to the PU of an SNS. Both PEOU and PU exerted a significant positive effect on the intention to use an SNS, supporting $\mathrm{H} 2$ and H3. The intention to use an SNS was positively related to actual SNS usage, supporting H4. The results 
pertaining to the paths from the exogenous variables to the TAM constructs were mixed. However, the data did not support H5a, H6a, and H7a pertaining to the effect of website quality features (service, information, and system quality) on PEOU. One of the three hypotheses concerning the effects of exogenous variables on PU was not supported (H6b) while H5b and $\mathrm{H} 7 \mathrm{~b}$ were supported. The results indicated that $\mathrm{CA}$ exerted a significant effect on PEOU and the intention to use an SNS (supporting H8a and H8c), but $\mathrm{H} 8 \mathrm{~b}$ pertaining to the effect on PU was not supported. Finally, two website qualities (information and system quality) were positively related to the $\mathrm{CA}$ construct ( $\mathrm{H} 9 \mathrm{a}$ and $\mathrm{H} 9 \mathrm{~b})$, although the data did not indicate that service quality was related to $\mathrm{CA}(\mathrm{H} 9 \mathrm{c})$.

The Indonesia model supported $\mathrm{H} 1$, indicating that PEOU was positively related to the PU of an SNS. Both PEOU and PU exerted a significant positive effect on the intention to use an SNS, supporting $\mathrm{H} 2$ and H3. The intention to use an SNS was also positively related to actual SNS usage, supporting $\mathrm{H} 4$. The results regarding the paths from the exogenous variables to the TAM constructs were also mixed. One of the three quality factors, information quality, exerted a significant effect on PEOU, supporting H5a. However, the data did not support H6a (the effect of system quality on PEOU) and H7a (the effect of service quality on PEOU). Only one of the three hypotheses on the effects of exogenous variables on PU was supported (H7b); H5b and H6b were not supported. All three CA hypotheses (H8a, H8b, and H8c) concerning the effects of CA on PEOU, PU, and intention to use an SNS were supported by significant effects. Finally, two of the three website quality features (information and system quality) were positively related to the CA construct (H9a and $\mathrm{H} 9 \mathrm{~b}$ ), although $\mathrm{H} 9 \mathrm{c}$ was not supported by the data (service quality).

\subsection{Multi-Group Model}

We also evaluated the moderating effect of the strength moderator-country using the LISREL multi-group comparison method. The objective of multi-group simultaneous path analysis was to determine whether the path coefficients for the relationships between the TAM, website quality features, and CA were the same for the two countries. We made one path invariant across the two countries and then freely estimated this path. The test indicated that the PEOU-PU (H1), information quality-PEOU (H5a), and CA-PU (H8b) paths in the Taiwan model were variant. The remaining paths were invariant. 
Table 7. Result of Hypotheses

\begin{tabular}{|c|c|c|c|c|c|}
\hline \multirow{2}{*}{ Hypothesis } & \multicolumn{2}{|c|}{ Taiwan } & \multicolumn{2}{|c|}{ Indonesia } & \multirow{2}{*}{$\begin{array}{l}\text { Muti-group } \\
\text { Moderate effect }\end{array}$} \\
\hline & coefficient & T-value & coefficient & T-value & \\
\hline H1 & 0.10 & $0.35^{\mathrm{NS}}$ & 0.27 & $2.68 * *$ & Taiwan $^{\text {NS }}<$ Indonesia** \\
\hline $\mathrm{H} 2$ & 0.30 & $4.62 * *$ & 0.25 & $2.64 * *$ & Taiwan $^{* *}=$ Indonesia** \\
\hline H3 & 0.20 & $3.08 * *$ & 0.23 & $2.65 * *$ & Taiwan $^{* *}=$ Indonesia $* *$ \\
\hline $\mathrm{H} 4$ & 0.47 & $7.22 * *$ & 0.56 & $7.20 * *$ & Taiwan $^{* *}=$ Indonesia ${ }^{* *}$ \\
\hline $\mathrm{H} 5 \mathrm{a}$ & 0.07 & $0.62^{\mathrm{NS}}$ & 0.38 & $3.49 * *$ & Taiwan $^{\text {NS }}<$ Indonesia** \\
\hline $\mathrm{H} 5 \mathrm{~b}$ & 0.24 & $2.34 * *$ & 0.11 & $0.99^{\mathrm{NS}}$ & Taiwan $^{* *}=$ Indonesia $* *$ \\
\hline H6a & 0.11 & $0.95^{\mathrm{NS}}$ & 0.05 & $0.48^{\mathrm{NS}}$ & Taiwan $^{\mathrm{NS}}=$ Indonesia $^{\mathrm{NS}}$ \\
\hline $\mathrm{H} 6 \mathrm{~b}$ & 0.04 & $0.38^{\mathrm{NS}}$ & 0.10 & $0.96^{\mathrm{NS}}$ & Taiwan $^{\mathrm{NS}}=$ Indonesia $^{\mathrm{NS}}$ \\
\hline $\mathrm{H} 7 \mathrm{a}$ & 0.15 & $1.50^{\mathrm{NS}}$ & -0.09 & $-1.02^{\mathrm{NS}}$ & Taiwan $^{\mathrm{NS}}=$ Indonesia $^{\mathrm{NS}}$ \\
\hline $\mathrm{H} 7 \mathrm{~b}$ & 0.35 & $3.58 * *$ & 0.22 & $2.72 * *$ & Taiwan $^{* *}=$ Indonesia ${ }^{* *}$ \\
\hline $\mathrm{H} 8 \mathrm{a}$ & 0.25 & $2.79 * *$ & 0.43 & $3.84 * *$ & Taiwan $^{* *}=$ Indonesia ${ }^{* *}$ \\
\hline $\mathrm{H} 8 \mathrm{~b}$ & 0.10 & $1.25^{\mathrm{NS}}$ & 0.25 & $2.29 *$ & Taiwan $^{\text {NS }}<$ Indonesia** \\
\hline $\mathrm{H} 8 \mathrm{c}$ & 0.34 & $4.38 * *$ & 0.39 & $3.70 * *$ & Taiwan $^{* *}=$ Indonesia $^{* *}$ \\
\hline H9a & 0.23 & $2.04 *$ & 0.34 & $3.03 * *$ & Taiwan $^{* *}=$ Indonesia** \\
\hline $\mathrm{H} 9 \mathrm{~b}$ & 0.45 & $3.87 * *$ & 0.42 & $3.78 * *$ & Taiwan $^{* *}=$ Indonesia $* *$ \\
\hline $\mathrm{H} 9 \mathrm{c}$ & 0.05 & $-0.45^{\mathrm{NS}}$ & 0.04 & $0.47^{\mathrm{NS}}$ & Taiwan $^{\text {NS }}=$ Indonesia $^{\text {NS }}$ \\
\hline$x^{2}$ & \multicolumn{2}{|c|}{619.772} & \multicolumn{2}{|c|}{477.089} & 1414.2661 \\
\hline df & \multicolumn{2}{|c|}{305} & \multicolumn{2}{|c|}{305} & 683 \\
\hline p-value & \multicolumn{2}{|c|}{0.00} & \multicolumn{2}{|c|}{0.00} & 0.00 \\
\hline RMSEA & \multicolumn{2}{|c|}{0.064} & \multicolumn{2}{|c|}{0.053} & 0.069 \\
\hline NFI & \multicolumn{2}{|c|}{0.935} & \multicolumn{2}{|c|}{0.959} & 0.933 \\
\hline NNFI & \multicolumn{2}{|c|}{0.960} & \multicolumn{2}{|c|}{0.985} & 0.964 \\
\hline CFI & \multicolumn{2}{|c|}{0.967} & \multicolumn{2}{|c|}{0.987} & 0.965 \\
\hline IFI & \multicolumn{2}{|c|}{0.967} & \multicolumn{2}{|c|}{0.987} & 0.965 \\
\hline
\end{tabular}

Note: NS = not significant; $* \mathrm{p}<0.05 ; * * \mathrm{p}<0.01$, model fit statistics of multi-group represented constrained multi-group model statistics.

\section{DISCUSSION AND CONCLUSION}

\subsection{Discussion}

TAM variables. Studies have successfully applied the TAM to $\mathrm{WWW}^{29}$, Web-based $\mathrm{IS}^{8}$, and virtual community ${ }^{12}$ contexts. This study used the TAM to comprehend users' perceptions of SNSs, which represent a new computer-mediated communication environment. Both PEOU and PU exerted significant effects on the intention to use SNSs in the two countries. Similarly, SNS usage intention in the two countries significantly affected actual usage behavior. In the Indonesia model, PEOU exhibited an indirect effect on adoption intention through PU, but this hypothesis was not supported in the Taiwan model. Dishaw and Strong ${ }^{88}$ argued that using the TAM beyond the workplace might be problematic because its fundamental constructs do not fully reflect the variety of user task environments. The duration and frequency of SNS visits may also influence the PEOU-PU 
relationship. Because information on an SNS is rapidly updated, users are easily informed of the vast amounts of information during a visit. Sometimes, users passively receive information and learn nothing significant when they have only a short time to visit or when their visits are less frequent ${ }^{89}$. In this situation, regular and extended visits to SNSs imply that users have more time to recall and retain important information. SNS providers should provide more external and intrinsic motivating factors ${ }^{58}$, such as more personal interfaces and settings, to increase users' intentions to use SNSs.

Website Quality Features and the TAM. In this research, information quality exerted different significant effects on PU and PEOU in Taiwan and Indonesia. The TAMs of the two countries did not support the system quality hypotheses, and service quality exerted a significant effect on PU but not on PEOU in the two countries. When surfing SNSs, the biggest challenge was to locate the information required to solve a problem ${ }^{38}$. Users can search large quantities of information for many purposes, such as entertainment or work ${ }^{44}$. Koufaris ${ }^{30}$ suggested that two types of information exist: non-value-added information and value-added information, which is enriching, satisfying, interesting, and helpful. High quality information (varied, complete, detailed, accurate, timely, relevant, and reliable) also increases user convenience and enables them to make superior decisions ${ }^{50}$. In this situation, SNS users might have distinct perceptions of received information. SNS providers should consider the concept of cognitive fit ${ }^{90}$, which refers to the fit between the data representation on SNSs and specific tasks that increase the match between PU, PEOU, and information quality. Some system quality and service quality hypotheses were unsupported, probably because most people use only one SNS. This research indicated that the vast majority of users use one SNS (Facebook). When websites implement a wide variety of technical features, users try to determine whether they conform to their expectations. When SNS users use only one SNS, they cannot compare its benefits with the benefits of other SNSs. To prevent this situation, SNS providers should improve user perceptions of PEOU and PU by adding or improving aesthetic features, structured content or layout, menu labels, hyperlink arrangements ${ }^{91}$, and Trust-e symbols ${ }^{56}$.

CA and the TAM. The results indicated that CA positively influenced only PEOU but did not influence PU in Taiwan. CA positively influenced PEOU and PU in Indonesia. SNSs provide several interactive functions to enable users to experience enjoyment and playfulness, such as games or the Facebook wall. Webster et al. ${ }^{92}$ argued that entertaining computer systems may be so enjoyable that employees neglect other tasks, indicating that too much flow may distract SNS users from other tasks ${ }^{15}$. SNS providers should 
enhance SNS search mechanisms to cope with user requests when users have fewer needs. Users who are less certain of what they are searching for are more likely to use search mechanisms that provide value-added information ${ }^{93}$. Value-added search mechanisms increase the internet use and decisional control and improve PU and flow ${ }^{94}$.

Website quality features and $\boldsymbol{C A}$. This study examined the relationships between three website qualities (information, system, and service quality) and CA. The results demonstrated that service quality was not supported in the two countries and that information and system quality were positively related to the PU of an SNS. It is difficult for SNS providers to satisfy users because flow is not a constant state; it is a function of control, content, and process characteristics, which influence the state of moving in and out of flow ${ }^{15}$. CA incorporates the temporal dissociation, focus immersion, heightened enjoyment, control, and curiosity dimensions of flow ${ }^{92,95}$. Therefore, SNS providers should frequently test the website functionality to capture and correct program bugs and ensure that SNS architecture supports a rapid response time and optimal system performance ${ }^{96}$ because a successful website must provide entertainment and information to add values to its users ${ }^{97}$.

\subsection{Managerial Implications}

This study demonstrated that PEOU and PU are significant antecedents of a member's intention to use an SNS, and they in turn influence actual usage behavior. Of the website quality features, service quality is an essential determinant of the PU of an SNS, and information quality and system quality are positively related to CA. CA enhances users' perception that an SNS is easy to use and thus increases their intention to use an SNS.

To attract more users to SNSs, SNSs have gradually started to integrate with other services, such as TV, movies, games, and products. SNS providers must test their systems before these new functions burden users with too many graphics and advertisements. Webpage multimedia richness and download speed must be balanced because a well-designed navigational structure can facilitate user perceptions of online control and clarify the meaning of interactive messages to achieve flow ${ }^{91}$.

Cross-cultural deception research is important due to the escalation of cross-cultural communication ${ }^{98}$. Many web users are worried about their identity security and do not intend to join SNSs. SNS providers should maintain the privacy of sensitive personal information and ensure system reliability to allow users to feel in control and mitigate their privacy concerns. 


\subsection{Future Research and Limitations}

This study contributes to the understanding of the determinants that attract users to SNSs and survive in the competitive social networking environment. Using the well-established TAM as a theoretical framework, critical exogenous variables consisting of three website qualities (information, system, and service quality), which comprise the interactive social networking system and CA construct, were proposed as significant contributors to understanding SNS usage behavior.

This study has certain limitations, and some aspects of this study require further research. First, this study focused on SNS users; thus, future studies could replicate this study with non-users. Second, most participants in this study were members of a specific SNS. The relationships hypothesized in this study should be examined further in other contexts. Finally, this study used scales and measures developed in Europe and America rather than in Asia, where this study was conducted. However, we used a back-translation procedure to ensure the equivalence of the questions in the scale. Future studies should test the appropriateness and fit of the model in Western countries.

Considering these limitations, future studies might improve our understanding of SNS success. First, web games are becoming increasingly popular on SNSs. Web games encourage users to join SNSs, although they have been criticized for contributing to other issues, such as game addiction $^{99}$. It is unclear how these interactive functions influence the evaluation of CA with SNSs and induce the intention to use SNSs. Second, along with the progression of mobile technology, access to SNSs drives the use of mobile internet services. Studies should examine whether non-users intend to use SNSs that make it convenient for them to connect with their friends or family because of the multimedia applications that they provide. In this situation, it is unclear how SNS providers should meet users' website quality preferences to balance download speed and graphic richness. Finally, SNS providers should focus on SNS interaction characteristics and recognize that SNS users enjoy various types of online behavior, such as receiving, supplying, and discussing information ${ }^{100}$. This focus will allow them to determine the information flow between SNS users, both as receivers and senders, and identify the optimal method for building word-of-mouth networks ${ }^{101}$. 


\section{REFERENCES}

[1] D. Boyd, Social network sites: Public, private, or what. Knowledge Tree, 13(1), p1-7, 2007.

[2] D. Boyd, Why youth (heart) social network sites: The role of networked publics in teenage social life. In D. Buckingham (Ed.), MacArthur foundation series on digital learning - Youth, identity, and digital media volume (p119-142). Cambridge, MA: MIT Press, 2007.

[3] D.M. Boyd, and N.B. Ellison, Social network sites: Definition, history, and scholarship. Journal of Computer-Mediated Communication, 13(1), p210-230, 2007. http://dx.doi.org/10.1111/j.1083-6101.2007.00393.x.

[4] N.B. Ellison, C. Steinfield, and C. Lampe, The benefits of Facebook "friends:" Social capital and college students' use of online social network sites. Journal of Computer-Mediated Communication, 12(4), p1143-1168,

2007. http://dx.doi.org/10.1111/j.1083-6101.2007.00367.x.

[5] Friends, Friendsters, and Top 8: Writing community into being on social network sites by D. Boyd. First Monday, 11(12), 2006. Retrieved on November 30, 2014, from http://www.firstmonday.org/ojs/index.php/fm/article/view/1418/1336.

[6] E. Hargittai, Whose space? Differences among users and non-users of social network sites. Journal of Computer-Mediated Communication, 13(1), p276-297, 2007. http://dx.doi.org/10.1111/j.1083-6101.2007.00396.x.

[7] B. Wellman, and M. Gulia, The network basis of social support: A network is more than the sum of its ties. Networks in the global village, p83-118, 1999.

[8] J.C.C. Lin, and H. Lu, Towards an understanding of the behavioural intention to use a web site. International Journal of Information $\begin{array}{lll}\text { Management, } & 20(3), & \text { p197-208, }\end{array}$ http://dx.doi.org/10.1016/S0268-4012(00)00005-0.

[9] D. Sledgianowski, and S. Kulviwat, Using social network sites: The effects of playfulness, critical mass and trust in a hedonic context. Journal of Computer Information Systems, 49(4), p74-83, 2009.

[10] W.H. DeLone, and E.R. McLean, The DeLone and McLean model of information systems success: A ten-year update. Journal of Management Information Systems, 19(4), p9-30, 2003.

[11] H.F. Lin, The impact of website quality dimensions on customer satisfaction in the B2C e-commerce context. Total Quality Management and Business Excellence, 18(4), p363-378, 2007. http://dx.doi.org/10.1080/14783360701231302.

[12] H.F.Lin, The role of online and offline features in sustaining virtual 
communities: an empirical study. Internet Research, 17(2), p119-138, 2007. http://dx.doi.org/10.1108/10662240710736997.

[13] S. Petter, W. DeLone, and E. McLean, Measuring information systems success: models, dimensions, measures, and interrelationships. European Journal of Information Systems, 17(3), p236-263, 2008. http://dx.doi.org/10.1057/ejis.2008.15.

[14] J. Chung, and F.B. Tan, Antecedents of perceived playfulness: An exploratory study on user acceptance of general information-searching websites. Information \& Management, 41(7), p869-881, 2004. http://dx.doi.org/10.1016/j.im.2003.08.016.

[15] D.L. Hoffman, and T.P. Novak, Marketing in hypermedia computer-mediated environments: Conceptual foundations. Journal of Marketing, 60(3), p50-68, 1996. http://dx.doi.org/10.2307/1251841.

[16] T.P. Novak, D.L. Hoffman, and Y.F. Yung, Measuring the customer experience in online environments: A structural modeling approach. Marketing $\quad$ Science, $19(1), \quad$ p22-42, 2000. http://dx.doi.org/10.1287/mksc.19.1.22.15184.

[17] R. Agarwal, and E. Karahanna, Time flies when you're having fun: Cognitive absorption and beliefs about information technology usage. MIS Quarterly, 24(4), p665-694, 2000. http://dx.doi.org/10.2307/3250951.

[18] M.H. Huang, Designing website attributes to induce experiential encounters. Computers in Human Behavior, 19(4), p425-442, 2003. http://dx.doi.org/10.1016/S0747-5632(02)00080-8.

[19] Y.X. Skadberg, and J.R. Kimmel, Visitors' flow experience while browsing a Web site: its measurement, contributing factors and consequences. Computers in Human Behavior, 20(3), p403-422, 2004. http://dx.doi.org/10.1016/S0747-5632(03)00050-5.

[20] Taiwan Network Information Center, A survey on broadband usage in Taiwan. Retrieved on November 30, 2014, from http://www.twnic.net.tw/download/200307/20130926d.pdf.

[21] Taipei Times, Taiwan likes Facebook, has highest penetration. Retrieved on November 30, 2014, from http://www.taipeitimes.com/News/biz/archives/2014/02/28/200358449 5.

[22] Internet World Stats, Usage and population statistics. Retrieved on February 15, 2015, from http://www.internetworldstats.com/stats3.htm.

[23] The Realtime Report, Indonesia is Facebook's 2nd largest market with 35 million users. Retrieved on November 30, 2014, from http://therealtimereport.com/2011/05/04/indonesia-is-facebooks-2nd-la rgest-market-with-35-million-users/.

[24] D. Straub, M. Keil, and W. Brenner, Testing the technology acceptance model across cultures: A three country study. Information \& 
Management, $\quad 33(1), \quad$ p1-11, 1997. http://dx.doi.org/10.1016/S0378-7206(97)00026-8.

[25] S. Durvasula, J.C. Andrews, S. Lysonski, and R.G. Netemeyer, Assessing the cross-national applicability of consumer behavior models: A model of attitude toward advertising in general. Journal of Consumer Research, 19(4), p626-636, 1993. http://dx.doi.org/10.1086/209327.

[26] D. Luna, L.A. Peracchio, and M.D. de Juan, Cross-cultural and cognitive aspects of web site navigation. Journal of the Academy of Marketing Science, 30(4), p397-410, 2002. http://dx.doi.org/10.1177/009207002236913.

[27] P. Legris, J. Ingham, and P. Collerette, Why do people use information technology? A critical review of the technology acceptance model. Information \& Management, 40(3), p191-204, 2003. http://dx.doi.org/10.1016/S0378-7206(01)00143-4.

[28] F.D. Davis, Perceived usefulness, perceived ease of use, and user acceptance of information technology. MIS Quarterly, 13(3), p319-340, 1989. http://dx.doi.org/10.2307/249008.

[29] J.-W. Moon, and Y.-G. Kim, Extending the TAM for a World-Wide-Web context. Information \& Management, 38(4), p217-230, 2001. http://dx.doi.org/10.1016/S0378-7206(00)00061-6.

[30] M. Koufaris, Applying the technology acceptance model and flow theory to online consumer behavior. Information Systems Research, 13(2), p205-223, 2002. http://dx.doi.org/10.1287/isre.13.2.205.83.

[31] C.L. Hsu, and H.P. Lu, Why do people play on-line games? An extended TAM with social influences and flow experience. Information \& Management, 41(7), p853-868, 2004. http://dx.doi.org/10.1016/j.im.2003.08.014.

[32] S.O. Mulero, Acceptance and impact of social networks marketing using extended technology acceptance model, Cape Peninsula University of Technology, 2012.

[33] A.M. Elkaseh, K.W. Wong, and C.C. Fung, Perceived Ease of Use and Perceived Usefulness of Social Media for e-Learning in Libyan Higher Education: A Structural Equation Modeling Analysis. International Journal of Information and Education Technology, 6(3), p192-199, 2016.

[34] H. van der Heijden, User acceptance of hedonic information systems. MIS Quarterly, 28(4), p695-704, 2004.

[35] U.R. Kulkarni, S. Ravindran, and R. Freeze, A knowledge management success model: Theoretical development and empirical validation. Journal of Management Information Systems, 23(3), p309-347, 2006. http://dx.doi.org/10.2753/MIS0742-1222230311.

[36] W.H. DeLone, and E.R. McLean, Measuring e-commerce success: 
Applying the delone \& mclean information systems success model. International Journal of Electronic Commerce, 9(1), p31-47, 2004.

[37] C. Liu, and K.P. Arnett, Exploring the factors associated with Web site success in the context of electronic commerce. Information \& Management, $38(1), \quad$ p23-33, 2000. http://dx.doi.org/10.1016/S0378-7206(00)00049-5.

[38] H. Chen, R.T. Wigand, and M.S. Nilan, Optimal experience of web activities. Computers in Human Behavior, 15(5), p585-608, 1999. http://dx.doi.org/10.1016/S0747-5632(99)00038-2.

[39] C.M. Finneran, and Z. Ping, Flow in computer-mediated environments: Promises and challenges. Communications of the Association for Information Systems, 15, p82-101, 2005.

[40] Tellegen, and G. Atkinson, Openness to absorbing and self-altering experiences ('absorption'), a trait related to hypnotic susceptibility. Journal of Abnormal Psychology, 83(3), p268-277, 1974. http://dx.doi.org/10.1037/h0036681.

[41] M. Csikszentmihalyi, and J. LeFevre, Optimal experience in work and leisure. Journal of Personality and Social Psychology, 56(5), p815-822, 1989. http://dx.doi.org/10.1037/0022-3514.56.5.815.

[42] J. Webster, and P. Hackley, Teaching effectiveness in technology-mediated distance learning. Academy of Management Journal, 40(6), p1282-1309, 1997. http://dx.doi.org/10.2307/257034.

[43] F.D. Davis, R.P. Bagozzi, and P.R.Warshaw, User acceptance of computer technology: A comparison of two theoretical models. Management Science, 35(8), p982-1003, 1989. http://dx.doi.org/10.1287/mnsc.35.8.982.

[44] V. Venkatesh, and F.D. Davis, A theoretical extension of the technology acceptance model: Four longitudinal field studies. Management Science, $\quad 46(2), \quad 186, \quad 2000$. http://dx.doi.org/10.1287/mnsc.46.2.186.11926.

[45] K. Mathieson, Predicting user intentions: Comparing the technology acceptance model with the theory of planned behavior. Information Systems Research, 2(3), p173-191, 1991. http://dx.doi.org/10.1287/isre.2.3.173.

[46] V. Venkatesh, and M.G. Morris, Why don't men ever stop to ask for directions? Gender, social influence, and their role in technology acceptance and usage behavior. MIS Quarterly, 24(1), p115-139, 2000. http://dx.doi.org/10.2307/3250981.

[47] M. Igbaria, N. Zinatelli, P. Cragg, and A.L.M. Cavaye, Personal computing acceptance factors in small firms: A structural equation model. MIS Quarterly, 21(3), p279-305, 1997. http://dx.doi.org/10.2307/249498.

[48] P.J. Hu, P.Y.K. Chau, O.R.L. Sheng, and K.Y. Tam, Examining the 
technology acceptance model using physician acceptance of telemedicine technology. Journal of Management Information Systems, $16(2)$, p91-112, 1999. http://dx.doi.org/10.1080/07421222.1999.11518247.

[49] K.A. Saeed, and S. Abdinnour-Helm, Examining the effects of information system characteristics and perceived usefulness on post adoption usage of information systems. Information \& Management, 45(6), p376-386, 2008. http://dx.doi.org/10.1016/j.im.2008.06.002.

[50] T. Ahn, S. Ryu, and I. Han, The impact of the online and offline features on the user acceptance of Internet shopping malls. Electronic Commerce Research \& Applications, 3(4), p405-420, 2004. http://dx.doi.org/10.1016/j.elerap.2004.05.001.

[51] A.L. Lederer, D.J. Maupin, M.P. Sena, and Y. Zhuang, The technology acceptance model and the World Wide Web. Decision Support Systems, 29(3), p269-282, 2000. http://dx.doi.org/10.1016/S0167-9236(00)00076-2.

[52] R.R. Nelson, P.A. Todd, and B.H. Wixom, Antecedents of information and system quality: An empirical examination within the context of data warehousing. Journal of Management Information Systems, 21(4), p199-235, 2005.

[53] M. Perkowitz, and O. Etzioni, Towards adaptive Web sites: Conceptual framework and case study. Computer Networks, 31(11), p1245-1258, 1999. http://dx.doi.org/10.1016/S1389-1286(99)00017-1.

[54] T. Ahn, S. Ryu, and I. Han, The impact of Web quality and playfulness on user acceptance of online retailing. Information \& Management, 44(3), p263-275, 2007. http://dx.doi.org/10.1016/j.im.2006.12.008.

[55] Z. Liao, and M.T. Cheung, Internet-based e-shopping and consumer attitudes: an empirical study. Information \& Management, 38(5), p299-306, 2001. http://dx.doi.org/10.1016/S0378-7206(00)00072-0.

[56] A. Parasuraman, V.A. Zeithaml, and A. Malhotra, E-S-QUAL: A multiple-item scale for assessing electronic service quality. Journal of Service Research, 7(3), p213-233, 2005. http://dx.doi.org/10.1177/1094670504271156.

[57] J.S. Siekpe, An examination of the multidimensionality of flow construct in a computer-mediated environment. Journal of Electronic Commerce Research, 6(1), p31-43, 2005.

[58] R.A. Shang, Y.C. Chen, and L.Shen, Extrinsic versus intrinsic motivations for consumers to shop on-line. Information \& Management, 42(3), p401-413, 2005. http://dx.doi.org/10.1016/j.im.2004.01.009.

[59] R.L. Wakefield, and D. Whitten, Mobile computing: A user study on hedonic/utilitarian mobile device usage. European Journal of Information Systems, 15(3), p292-300, 2006. 
http://dx.doi.org/10.1057/palgrave.ejis.3000619.

[60] L. Lapointe, and S. Rivard, A triple take on information system implementation. Organization Science, 18(1), p89-107, 2007. http://dx.doi.org/10.1287/orsc.1060.0225.

[61] V. Venkatesh, Determinants of perceived ease of use: Integrating control, intrinsic motivation, and emotion into the technology acceptance model. Information Systems Research, 11(4), p342-365, 2000. http://dx.doi.org/10.1287/isre.11.4.342.11872.

[62] M.Y. Yi, and Y. Hwang, Predicting the use of web-based information systems: self-efficacy, enjoyment, learning goal orientation, and the technology acceptance model. International Journal of Human-Computer Studies, 59(4), p431-449, 2003. http://dx.doi.org/10.1016/S1071-5819(03)00114-9.

[63] V. Venkatesh, C. Speier, M.G. Morris, User acceptance enablers in individual decision making about technology: Toward an integrated model. Decision Sciences, 33(2), p297-316, 2002. http://dx.doi.org/10.1111/j.1540-5915.2002.tb01646.x.

[64] D.J. Bem, Self-perception theory. Advances in experimental social psychology, $\quad 6, \quad \mathrm{p} 1-62$, http://dx.doi.org/10.1016/S0065-2601(08)60024-6.

[65] M.J. Sanchez-Franco, WebCT - The quasimoderating effect of perceived affective quality on an extending Technology Acceptance Model. Computers \& Education, 54(1), p37-46, 2010. http://dx.doi.org/10.1016/j.compedu.2009.07.005.

[66] Y.X. Skadberg, A.N. Skadberg, and J.R. Kimmel, Flow Experience and Its Impact on the Effectiveness of a Tourism Website. Information Technology \& Tourism, 7(3/4), p147-156, 2005. http://dx.doi.org/10.3727/109830505774297238.

[67] N. Singh, G. Fassott, M.C. Chao, and J.A. Hoffmann, Understanding international web site usage: A cross-national study of German, Brazilian, and Taiwanese online consumers. International Marketing Review, 23(1), p83-97, 2006. http://dx.doi.org/10.1108/02651330610646304.

[68] M. Carli, A.D. Fave, and F. Massimini, The quality of experience in the flow channels: Comparison of Italian and US students. In $\mathrm{M}$. Csikszentmihalyi and I. Csikszentmihalyi (Eds.), Optimal experience: Psychological studies of flow in consciousness (p288-306), Cambridge, Cambridge University Press, 1988.

[69] K. Lee, K. Joshi, and M. Bae, A cross-national comparison of the determinants of customer satisfaction with online stores. Journal of Global Information Technology Management, 12(4), p25-51, 2009. http://dx.doi.org/10.1080/1097198X.2009.108565020.

[70] ADMA, Asia pacific digital marketing yearbook 2009. Retrieved on 
November 28, 2014, from http://www.asiadigitalmarketingyearbook.com/.

[71] H.W. Sinaiko, and R.W. Brislin, Evaluating language translations: Experiments on three assessment methods. Journal of Applied Psychology, 57(3), p328-334, 1973. http://dx.doi.org/10.1037/h0034677.

[72] B.M. Byrne, Structural equation modeling with LISREL, PRELIS, and SIMPLIS: Basic concepts, applications, and programming: Psychology Press, 2013.

[73] J.D. Wisner, A structural equation model of supply chain management strategies and firm performance. Journal of Business Logistics, 24(1), p1-26, 2003. http://dx.doi.org/10.1002/j.2158-1592.2003.tb00030.x.

[74] J.E. Bailey, and S.W. Pearson, Development of a tool for measuring and analyzing computer user satisfaction. Management Science, 29(5), p530-545, 1983. http://dx.doi.org/10.1287/mnsc.29.5.530.

[75] H.F. Lin, Determinants of successful virtual communities: Contributions from system characteristics and social factors. Information \& Management, 45(8), p522-527, 2008. http://dx.doi.org/10.1016/j.im.2008.08.002.

[76] K.M. Kimery, and M. McCord, Third party assurances: mapping the road to trust in eretailing. Journal of Information Technology Theory and Application (JITTA), 4(2), p63-82, 2002.

[77] H.F. Lin, and G.G. Lee, Determinants of success for online communities: an empirical study. Behaviour \& Information Technology, 25(6), p479-488, 2006. http://dx.doi.org/10.1080/01449290500330422.

[78] Parasuraman, V.A. Zeithaml, and L.L. Berry, SERVQUAL: A multiple-item scale for measuring consumer perceptions of service quality. Journal of Retailing, 64(1), p12-40, 1988.

[79] C.C. Wang, Y.H. Hsu, and W Fang, Acceptance of technology with network externalities: an empirical study of internet instant messaging services. Journal of Information Technology Theory and Application (JITTA), 6(4), p15-28, 2005.

[80] J.C. Anderson, and D.W. Gerbing, Structural equation modeling in practice: A review and recommended two-step approach. Psychological Bulletin, 103(3), p411-423, 1988. http://dx.doi.org/10.1037/0033-2909.103.3.411.

[81] J.F. Hair, R.E. Anderson, R.L. Tatham, and W. Black, Multivariate data analysis, Prentice Hall, Upper Saddle River, 1998.

[82] C. Fornell, A second generation of multivariate analysis. Vol.2: Measurement and evaluation, New York, NY: Praeger Publishers, 1982.

[83] C. Fornell, and D.F. Larcker, Evaluating structural equation models 
with unobservable variables and measurement error. Journal of Marketing Research (JMR), 18(1), p39-50, 1981. http://dx.doi.org/10.2307/3151312.

[84] R.P. Bagozzi, and Y. Yi, On the evaluation of structural equation models. Journal of the Academy of Marketing Science, 16(1), p74-94, 1988. http://dx.doi.org/10.1007/BF02723327.

[85] K.A. Bollen, Structural equations with latent variables. New York, NY: Wiley, 1989. http://dx.doi.org/10.1002/9781118619179.

[86] M.B. Myers, R.J. Calantone, T.J. Page Jr, and C.R. Taylor, Academic insights: An application of multiple-group causal models in assessing cross-cultural measurement equivalence. Journal of International Marketing, $\quad 8(4), \quad$ p108-121, 2000. http://dx.doi.org/10.1509/jimk.8.4.108.19790.

[87] R. Garcia, and D. Kandemir, An illustration of modeling moderating variables in cross-national studies. International Marketing Review, 23(4), p371-389, 2006. http://dx.doi.org/10.1108/02651330610678967.

[88] M.T. Dishaw, and D.M. Strong, Extending the technology acceptance model with task-technology fit constructs. Information \& Management, 36(1), p9-21, 1999. http://dx.doi.org/10.1016/S0378-7206(98)00101-3.

[89] K. de Valck, G.H. van Bruggen, and B. Wierenga, Virtual communities: A marketing perspective. Decision Support Systems, 47(3), p185-203, 2009. http://dx.doi.org/10.1016/j.dss.2009.02.008.

[90] Vessey, Cognitive fit: A theory-based analysis of the graphs versus tables literature. Decision Sciences, 22(2), p219-240, 1991. http://dx.doi.org 10.1111/j.1540-5915.1991.tb00344.x.

[91] Z. Yang, M. Jun, and R.T. Peterson, Measuring customer perceived online service quality. International Journal of Operations \& Production Management, 24(11), p1149-1174, 2004. http://dx.doi.org/10.1108/01443570410563278.

[92] J. Webster, L.K. Trevino, and L. Ryan, The dimensionality and correlates of flow in human-computer interactions. Computers in Human Behavior, 9(4), p411-426, 1993.

[93] M. Koufaris, A. Kambil, and P.A. Labarbera, Consumer behavior in web-based commerce: An empirical study. International Journal of Electronic Commerce, 6(2), p115-138, 2001.

[94] C. Mathwick, and E. Rigdon, Play, flow, and the online search experience. Journal of Consumer Research, 31(2), p324-332, 2004. http://dx.doi.org/10.1086/422111.

[95] L.K. Trevino, J. Webster, Flow in computer-mediated communication: Electronic mail and voice mail evaluation and impacts. Communication Research, 19(5), p539-573, 1992. http://dx.doi.org/10.1177/009365092019005001.

[96] M.L. Korzaan, Going with the flow: Predicting online purchase 
intentions. Journal of Computer Information Systems, 43(4), p25-31, 2003.

[97] T.H. Nelson, The right way to think about software design. In B. Laurel (Ed.), The art of human-computer interface design (p235-243). Reading, MA: Addison-Wesley, 1990.

[98] C.C. Lewis, and J.F. George, Cross-cultural deception in social networking sites and face-to-face communication. Computers in Human Behavior, 24(6), p2945-2964, 2008. http://dx.doi.org/10.1016/j.chb.2008.05.002.

[99] T. J. Chou, and C. C. Ting, The role of flow experience in cyber-game addiction. CyberPsychology \& Behavior, 6(6), p663-675, 2003. http://dx.doi.org/10.1089/109493103322725469.

[100]P. Kiecker, and D. Cowles, Interpersonal communication and personal influence on the internet: A framework for examining online word-of-mouth. Journal of Euromarketing, 11(2), p71-88, 2002.

[101]J.M. Bristor, Enhanced explanations of word of mouth communications: the power of relationships. Research in Consumer Behavior, 4(1), p51-83, 1990. 
